\title{
At the intersection of the global and the local: representations of male homosexuality in fictions by Pai Hsien-yung, Li Ang, Chu Tien-wen and Chi Ta-wei
}

\author{
LIANG-YA LIOU
}

This article seeks to explore the representations of male homosexuality in four Taiwan fictions in relation to how the local and the global intersect. The process of globalisation has become intense over the past fifty years. More than ever space and time seem compressed through the spread of the new communication technology, media, trade, finance and commodity circulation, as well as travel and migration. This does not, however, mean that a homogeneous, integrated global culture is at hand or welcome. Instead, homogenisation and unification are not uncontested, since not only do the non-Western nation-states and cultures talk back to the West, but the West is shown to be heterogeneous. ${ }^{1}$ Mike Featherstone argues that the globalisation process actually opens up 'a dialogical space in which we can expect a good deal of disagreement, clashing of perspectives and conflicts, not just working together and consensus'. ${ }^{2}$ There are more and more hybrid sites of meaning. As Homi Bhabha notes in his book The Location of Culture, "in the fin de siècle, we find ourselves in the moment of transit where space and time cross to produce complex figures of difference and identity, past and present, inside and outside, inclusion and exclusion'. ${ }^{3}$

In the fin de siècle, Taiwan also finds itself in a phase in which 'globalization and localization are inextricably bound together', ${ }^{4}$ especially in the terrain of gender and sexuality. This past decade witnessed the greatest change in notions of gender and sexuality in Taiwan. ${ }^{5}$ With the rise of gay/lesbian/queer movements in the 1990s, male homosexuality, lesbianism and queer sexuality, which used to be seen as unspeakable and unrepresentable in Taiwan fiction, have become one of the hottest subject matters. While one may say that this phenomenon is in part brought about by globalisation, it also has to do with the lifting of martial law in 1987. Moreover, interest in gays, lesbians and queers entails numerous small fights. Sometimes it seems like a sheer contention between the local and the global over notions of gender and sexuality. Closely examined, the dichotomy is too facile, since neither the local nor the global can be seen as monolithic. But the globalisation of gay/lesbian/queer movements does help release what was suppressed and left out in the local. Fictional 
representations of male homosexuality, lesbianism and queer sexuality reveal an even more complicated picture of the intersection of the local and the global.

Before I discuss Taiwan fictional representations of male homosexuality, a brief introduction to Taiwan's lesbian/gay/queer movements in the 1990s is needed, even though the fictions I deal with are not limited to those of the 1990s. This introduction serves two ends. First, it will give a glimpse of the movements' complicated politics in relation to the local and the global. Second, it will provide a frame of reference with which to read fictional texts and look back upon earlier periods.

Lesbian and gay discourses were brought into Taiwan with an almost twenty-year temporal gap vis-à-vis their Western counterparts, and just a year or two ahead of the introduction of queer discourse. The time-lag is telling of the repressive socio-political climate under martial law before 1987, when even the women's movement had insufficient social influence. In fact, the years from 1979 to 1989 saw the struggle against the authoritarian one-party rule of the Kuomintang (or Chinese nationalists), with the demand for democratisation accompanied by a demand for recognising the importance of Taiwanese culture rather than sticking to the ideology that the Kuomintang held would eventually beat communism and recover the Chinese mainland. Founded on the preliminary success of democratisation around 1987-1989, and enabled by a public need for respite from the standoff between pro-independence and pro-unification camps over the issue of national identity, the feminist movement quickly flourished as an important social movement after the lifting of martial law. Lesbian and queer movements started out as branches within the feminist movement, when the activists, unable to fully come out, joined the women's movement to secretly promote gay-positive consciousness and succeeded in obtaining support from within the movement. The first lesbian group, 'Between Us', was founded in 1990, and the first sign of a queer movement took shape in the 'Queer Special Issue' of the New Left journal The Isle's Margin in 1994, with Chi Ta-wei, Lucifer Hung and Tan Tang-mo as guest editors. Queer commentary, however, had already appeared earlier in Liang Nung-gun's book Pleasure and Sexual Difference (1989) and Chang Hsiao-hung's Postmodernism/Woman (1993). The gay movement kept a lower profile, for the activists could not disguise themselves as feminists. Since gay, lesbian and queer discourses were introduced to Taiwan at about the same time, the trajectories of the three movements here are quite different from those in the West. Whereas the queer movement in the West was built on the success of the identity politics of the gay and lesbian movements, Taiwan's gay, lesbian and queer movements proceeded simultaneously, with some of the activists working for more than one movement.

Around 1995-1996 a new coalition between the lesbian/queer movements and the gay movement in Taiwan was formed, which made these movements somehow stand out and seize a lot of media attention from the feminist movement. In 1996, the Gay/Lesbian/Queer Space Action Front launched a series of protests against the Taipei municipal government's decision to convert Taipei's New Park into the 2-2-8 Memorial Park. In a way, the conflict can be seen as an unfortunate clash between Taiwanese nationalism and the gay/lesbian/ queer movement. ${ }^{6}$ Whereas the conversion represented a belated official recogni- 
tion of the dark, traumatic history related to the 2-2-8 incident in 1947 and a commemoration of those killed as a result of it, it also symbolically erased the memories of the park as a space of male homosexual public sex in the past. Though the decision was not overturned, the protests successfully revived public memories, and showed gay/lesbian/queer solidarity. ${ }^{7}$ But the event caused conflict between lesbian/queer feminists and mainstream feminists. Thus, when the activists sought to come out and raise gay rights issues within the feminist movement, mainstream feminists, who feared this course might dominate the direction of the movement, snubbed them. A few feminists even had homophobic reactions. In consequence, lesbian (and gay) rights activists either split off into a separate organisation, or inclined toward sexual liberationist feminism.

Taiwan lesbian/gay/queer movements not only draw from the discourse and strategies of their Western (often US) counterparts but also often use the Western examples as a means of mobilisation. In spite of this, these movements adapt Western discourse and strategies to the Taiwanese context. Homi Bhabha points out that 'the similitude of the symbol as it plays across cultural sites must not obscure the fact that repetition of the sign is, in each specific social practice, both different and differential'. ${ }^{8}$ The movements' adaptation to a Taiwanese context indicates a desire to achieve their goals within the shortest time, hence a strategic avoidance, at the earlier stage, of confrontation with an oppressive atmosphere of homophobia and heterosexism. A case in point is the appropriation of the word 'tung-chi' (or 'comrade'), first used by Hong Kong Chinese, to translate 'gay' in an effort to re-name homosexuals positively. Compared with 'gay' in the Western context, however, the translation stresses solidarity but sheds 'gayness'. 'Tung-chi' (or 'comrade') then becomes a code word or a double-voiced word that is in wider circulation than 'homosexual', and sometimes the word also means 'queer'. Likewise, the translation of 'queer' into a newly coined word 'ku-err' deliberately strips it of its English context and turns it into a code word to avoid censorship. Carrying the connotation of 'cool' and 'stylish', 'ku-err' is so outlandish that it almost becomes a floating signifier after it turns into a cultural fad, which is in tune with the carnivalesque spirit with which the queer movement wants to be associated. Thereafter, more adequate translations such as 'kuai-tai' and 'pien-tai' have come into use to allude to the original context of the use of 'queer'.

As in the West, the local queer movement generally adopts more defiant and seductive strategies. After the coalition of gay/lesbian/queer movements in 1995-1996, the movements turned to gayer and bolder strategies. These included publicising gays' and lesbians' choices of top ten icons, which included famous and presumably heterosexual pop singers and politicians, and the demonstration by a bunch of activists, who donned masks and dressed in rainbow colours, against the municipal government on the issue of the New Park. Since individuals coming out still faced great pressure, the activists donning masks adopted the strategy of the so-called 'collective coming out' to promote gay-positive consciousness. ${ }^{9}$ Activism also took the form of debating in the public forum or in internet discussions (for example, in challenges to homophobic speech in the media and on the college campus), holding gay/lesbian/queer film festivals, etc. Feeling the lack of a gay or lesbian subculture with which they could identify 
in $1995,{ }^{10}$ the activists used the internet to connect with individual gays, lesbians and queers, in order to create a new subculture. The differences within the gay, lesbian, queer population were great, as Chi Ta-wei notes from the internet discussions in $1995 .{ }^{11}$ Chi observes that in 1995 the conservatives and liberals were often in the majority, while the radicals were silenced in the hot debates. ${ }^{12}$ This may not be the case now. The internet also helped to mobilise underground gay/lesbian circles and cliques. Thus, while there is not yet an equivalent of pride marches in Taiwan, conferences on gay/lesbian/queer topics with gaypositive appeal often draw a great number of self-declared lesbians, gays and queers.

Gay/lesbian/queer movements in Taiwan are sometimes criticised as elitist in character, meaning that their core members are mostly college students or academics, and that these people's connection with other underground gay and lesbian circles and cliques, especially of different social classes or generations, may be slim. This seems to be a tension or clash between the local (those whose associations are defined by locality) and the global (those who are plugged into international modes of cultural politics). But the fight with the municipal government over Taipei's New Park partially connects the movements with the lower-class gay circles.

Writers whose fictions deal with male homosexuality, lesbianism and queer sexuality are not necessarily involved in the movements. They may draw from personal experiences, books, movies or MTVs. Here again the global and the local intersect. Gay and lesbian subcultures already existed in Taiwan in uni-sex communities such as girls' middle schools, boys' middle schools, the army, prisons, etc. Classic Chinese and Western fictions about male homosexuality are also well known. Since the mid-1980s, there has been a wave in Europe and North America of movies and MTVs portraying gays, lesbians and queers. After the lifting of martial law, these Western cultural commodities were imported more quickly than ever. The prestigious Golden Horse international film festival, the largest and most important film festival in Taiwan, has included gay and lesbian movies since 1990. The festival has allotted a special section to movies about gays, lesbians and queers since 1993, which created a great sensation among intellectual and artistic circles for several years. Gays, lesbians and queers have also appeared recurrently in pop movies and MTVs made in the West and Hong Kong. The importance of gay-related art and literature was gradually established in Taiwan, as Taiwan-produced gay films received internationally acclaimed film awards in 1994 and $1996,{ }^{13}$ and as the China Times Prize for Novels was awarded to gay and lesbian novels in 1994 and $1995 .{ }^{14}$

What we see, then, is an intricate scene of cultural translation, which in its fictional representation takes on an even more complicated form. In what follows I will discuss representations of male homosexuality in four Taiwan fictions in relation to the local and the global. In these fictions, very often one major character had been or is currently living abroad, or has foreign friends. The view of this character may or may not be endorsed by the central narrating voice in the text, but constitutes an important discourse that serves to parallel or contrast with more local views in the text. Another important theme is gay men's relationship with nationalism and ethnicity, which addresses the cultural 
specificity of Taiwan, but which is also related to the change in Taiwan geopolitics. I will examine the sexual politics of these fictions respectively by taking account of these two aspects.

\section{Crystal Boys: the homecoming of the guilt-ridden homosexual son}

Seen retrospectively, Pai Hsien-yung's Crystal Boys (1983), ${ }^{15}$ which may be the first Taiwan novel that explicitly deals with male homosexuality, seems totally untouched by the Western gay movement. Both its liberal humanism and reconciliation with paternal authority sound too conservative today. The novel was 'scandalous', however, when first published, and remained so for a long time. Since it focuses on male homosexual prostitutes who come from broken families, many critics feel justified in equating male homosexuals with homosexual prostitutes and in alleging that male homosexuality is both lustful and caused by broken families. ${ }^{16}$ Not until 1993 does a re-reading appear to counter such criticism. ${ }^{17}$ The book's importance is, however, underlined by the repeated references to it in the controversy over the gay cruising space in Taipei's New Park.

Presenting a male homosexual underworld surrounding the homosexual prostitutes based in Taipei's New Park (its renaming as the 2-2-8 Memorial Park took place in 1996), Crystal Boys seems to be full of local colour. While prostitution was not an uncommon theme in Taiwanese fiction from the 1960s to the $1980 \mathrm{~s},{ }^{18}$ male prostitution was taboo. The novel is in a sense a roman-àclef. The readers are supposed to believe that the novel is based on real-life experience of this secret male homosexual world, with some minor characters referring to famous artists and movie stars. But the author, who was well known for his successful portrayals of exilic, nostalgic mainlanders who followed the Kuomintang to Taiwan after the Communist take-over of China in 1949, published this 'scandalous' novel while at the University of California in Santa Barbara, where he had taught for several years. One wonders if he could have survived the homophobic social pressure at that time, had he been living in Taipei. On the other hand, since the author cannot have been ignorant of the North American gay movement, the novel may be an attempt on his part to pioneer a Taiwan gay movement by speaking about and for the male homosexuals that he knew. Prior to the gay movement in the 1990s, the author seems to have aimed at a 'collective coming out' through his portrayals of a cohort of self-identified male homosexuals partying together and of male homosexual activities in high school and the army. His depiction of male homosexuality in the Chinese army during the Sino-Japanese War may well be an attempt at giving Taiwanese male homosexuality a Chinese history.

As if anticipating the reactions of mainstream society, however, the novel is divided in both its politics and tone. It is at once defiantly festive and traumatically guilt-ridden, but one must say that very often the latter is predominant, in compliance with mainstream values. The very title 'nieh-tzu', which can mean 'bad son', 'son born of a concubine', 'monster', and 'the bane', is revealing of the fact that male homosexuals in 1960-1970s Taiwan are seen from the traditional view of how a son is supposed to carry on the patrilineal 
family line and fulfil his filial duty to the father. The title, then, is indicative of the fact that the greatest difficulty for gays, lesbians and queers in Taiwan is in fighting the oppression of the patriarchal family and familialism. The novel hardly dismisses the guilt of the homosexual son for his traditional father, even though the father's expulsion condemns the son to roam the underworld of the city. But the novel is also covertly defiant in naming the male homosexuals (especially the young homosexual prostitutes) as 'ching-chuan niao' (or 'young birds'). Taipei's New Park becomes a shelter for these homosexuals who are expelled from home and school, outcast and outlawed by society. The author suggests the self-conscious anti-establishment defiance of the homosexual underworld: 'We as a nation are a fickle, unruly people'. ${ }^{19}$ The cohort of male homosexuals who walk round and round the compounds beside the lotus pond in the park consumed by their desire is indomitable and unrepentant. Their very presence and their carnivalesque dinner parties suggest solidarity.

Yet strangely, the male homosexual relationship, if depicted at all in the novel, is shown as lacking in pleasure and enjoyment. It is either the lust, pain and humiliation of male homosexual prostitution, or the painful love relationship of legendary proportions between Wang Kuei-lung, the son of a mainlandergeneral, and Ah-fung, a native-born homosexual prostitute, which ends in the former's killing of the latter. Refracted through the accounts of different men, the wildness of Ah-fung, the archetypal young bird, is less celebrated ${ }^{20}$ than regarded as somehow doomed and connected with his being a bastard and orphan. Wang's passion for Ah-fung, too, is portrayed as uncontrollable and suffocating. This predominantly tragic tone may have something to do with the generally anti-sex culture of the 1960s to 1980s. In Pai Hsien-yung's earlier collection of short stories, Taipei People, too, the critic Ou-yang Tzu notes a spiritual/carnal dichotomy and a valorisation of the former over the latter. ${ }^{21}$ Even though Chang Sung-sheng questions the validity of this dichotomy in its application to both Crystal Boys and Taipei People, ${ }^{22}$ the reticence about sexual joys in Crystal Boys seriously undermines its subversive potential. Such reticence may be a calculated move on the part of the author in order not to outrage his conservative reader. And the tragic tone may imply an indirect indictment against the society which marginalises male homosexuals, condemning them to extremely limited erotic relationships. Still, the book's representation of homosexual relationships strikes one as hardly gay-positive.

Wang Kuei-lung, depicted as returning to Taipei after spending ten years in hiding in New York City, is in a sense the authorial surrogate and sheds more light on the intersection between the local and the global. Outcast by his general-father, who was shocked by the scandal attaching to his son, Wang had escaped to the United States and lived under a false name. Emotionally paralysed after his killing of Ah-fung, he had been sexually abused by a gang in New York's Central Park, which reduced him to a living skeleton. Unlike Taipei's New Park, Central Park was a horrible place to him; even the 'young birds' he encountered there had been sexually victimised and were under constant life threat in addition to suffering from drug addiction and venereal disease. Wang's case is significant in that it both demystifies the American Dream celebrated in numerous accounts at that time and is different from that of many upper- 
middle-class mainlanders' children, who are taught by their parents to view Taiwan as a temporary dwelling-place. Wang sees his American experience as a forced exile from home, which only ends with his father's death. He returns as a prodigal son with deep remorse for his late father.

Wang's return to the father and fatherland suggests an appeal for the understanding, tolerance and protection of the father(-land)-whatever grievances he may have borne against him/it-rather than a demand for his right as a homosexual. Symbolically, this seems to imply a 'Chinese' way of resolving the issue, which is all the more clear as Papa Fu, who mourns the loss of his own homosexual son, becomes the surrogate father of Wang and the literal protector of the homosexual underworld. As Chang Sung-sheng puts it so well: 'The son, by pleading with the father for understanding and forgiveness, seeks to be reintegrated into the dominant social order, the traditional social edifice that is bastioned by "loyalty and filial piety". 23 There is a disturbingly feudalistic overtone in soliciting the patronage of Papa $\mathrm{Fu}$, since he, like Wang's own father, had been an army officer in the Sino-Japanese War and is a powerful mainlander who has good connections in the Kuomintang. The patronage, rather than legitimating homosexuality, operates by giving privileges to some practitioners, while the latter take it upon themselves to act as loyal subordinates or filial sons.

Father-son relationships are a haunting theme throughout the novel. Homosexual prostitutes like Ah-ching and Little Jade also seek surrogate fathers either in or out of their erotic relationships. But the benevolence of Papa $\mathrm{Fu}$ is rare. And if Wang, born of the upper class, disparages his American experience and craves reconciliation with his father, the same may not be said of other homosexuals. A different politics is suggested in Little Jade, a resourceful homosexual prostitute and a bastard born of a Taiwanese female prostitute.

Little Jade is eager to find his biological father, who is a Taiwanese Japanese merchant. Cunning and undaunted by the danger of prostitution, he makes a point of knowing (Taiwanese) Japanese clients who can take him to Japan, and eventually succeeds in jumping ship. The novel remains open-ended as to whether he will find his father or not, but his assertion of his birthright to the father who had abandoned him while an infant may be a symbolic assertion of his right as a homosexual. His letters to Ah-ching are filled with excitement about his new job as a waiter in a restaurant and about the much larger group of 'young birds' in Tokyo. Thus, going abroad may imply hope and positive connection with an international, gay community. Moreover, Little Jade's search for his father can be seen as a recognition on the author's part of Taiwan's past as a colony of Japan, as well as Taiwanese attachment for Japan and the Japanese. For many native Taiwanese, life under the authoritarian rule of mainlanders may be no better, even worse, than that under the authoritarian rule of the Japanese. This recognition, which must be hard for the author, whose father had fought in the Sino-Japanese War, amounts to an understanding of the cultural hybridity of Taiwan.

The contrast between Little Jade and Wang Kuei-lung sums up the divided politics of the book as a whole. Wang represents the dominant voice of the text, whose liberal humanism is endorsed by the author, whereas Little Jade stands for 
the more rebellious, defiant marginal voice, whose subversive potential anticipates the activism in the 1990s.

\section{2 'A Romance about Forbidden Desire': a satire on First World gay men}

Li Ang's short story 'A Romance about Forbidden Desire'24 (1989) is 'gayer' (in the double sense) in its presentation of male homosexuality than Crystal Boys. For one thing, it is devoid of the obsession with the father-son relationship; for another, pleasure and power games take the place of the guilt and pain in Crystal Boys, since the story is a satire on the superiority of First World gay men over Third World gay men. The female author Li Ang vividly and explicitly portrays the sensuality of male homosexual intercourse, in ways that are consistent with her sexual liberationist feminist position. This boldly pro-sex stance anticipates similar sexual politics in 1990s gay/lesbian/queer activism. Even more intriguing is the way the novel's sexual politics is related to its racial and ethnic politics.

In a sense, 'A Romance about Forbidden Desire' re-writes Crystal Boys from a postcolonial perspective by connecting the male homosexual underworld of Taipei's New Park with the gay community in Los Angeles. Wang Ping, a Chinese American intellectual and an immigrant from Taiwan ${ }^{25}$ who lives with his American boyfriend Ted Brown in LA, falls in love with Lin Chih-wen, a Taiwanese homosexual prostitute, after a one-night stand and eventually takes Lin to LA. A university professor with a Ph.D., Wang is portrayed as even more 'Americanised' in lifestyle than Brown: Wang has many a one-night-stand lover in addition to his relationship with Brown, whereas Brown does not. He comes to know Lin through Brown, who as a former student in Asian Studies visits the New Park seeking adventures and there encounters Lin. Jealous and curious about Brown's one-night stand with Lin and flattered by Lin's recognition of his reputation as a literary critic, Wang happily accepts Lin's date. After their night together Wang flies back to LA and Lin writes to him expressing his fidelity to and love for him as well as his envy of him as a free man who can fly like a bird.

The story abounds with comic satire on First World gay men. A reversal of action takes place six months later, when Wang returns to Taipei to woo Lin and is turned down by the latter. The frustrated Wang writes to Brown for help, and they both try condescendingly to psychoanalyse Lin. Brown sees Lin as a poor Third World boy suffering from fear of losing Wang, and Wang sees Lin as blocked by his poor education and family background (with a 'bad combination' of a China-born father and a Taiwanese mother) from exposure to more advanced ideas of love and sex. Moreover, Wang considers Lin's lack of desire to go abroad ${ }^{26}$ as a serious problem. Both conclude that Lin is hence rendered incapable of love and being loved and that he has to cruise in the New Park. But an anonymous female narrator ${ }^{27}$ suggests that their assumed superiority as First World intellectuals prevents them from knowing the real Lin. Since Wang is a Chinese American who never regards Taiwan as home, ${ }^{28}$ he patronises Lin the pariah just as he patronises Taiwan the international pariah. ${ }^{29}$ Brown's pity and love for Third World people is self-serving in that he displays Americans' hidden need to assert their cultural superiority after Japan produced better cars 
and electrical appliances than the United States in the late 1980s. As an observer, the female narrator feels that Lin simply does not love Wang.

The female narrator underscores Lin's subjectivity. Under the veneer of quietness and fragility, Lin is a complicated man who has the capacity for love and passion and is his own master. Lin not only rejects the nickname of 'Little Honey' as derogatory, but also hates to be seen as Wang's toy. The narrator mocks Wang's failure to conquer Lin. The usually demanding, merciless and stingy Wang has been devoted for two whole years to the much younger, less experienced and less knowledgeable man. But, except for the first one-night stand, he gets no chance of having any physical contact with Lin. The satire on First World gay men climaxes with Wang taking Lin to tour LA. In order to patronise Lin, Wang taunts him with his difficulty in accosting any gay man on Santa Monica Boulevard in West Hollywood, only to be embarrassed by Lin's accusation that all Wang wants is to sleep with him. Lin refuses Wang. Even though he is a freelance homosexual prostitute, Lin dominates Wang, who has to send him back to Taiwan.

The connection of Taipei gay men with LA gay men evokes the globalisation process, in that the former are brought into contact with the First World elite supposedly representing global values. Yet the portrayal of the subtle power games in the cross-national, cross-ethnic relationship celebrates the subjectivity of Taiwan gay men vis-à-vis First World gay men, which is clearly a symbolic assertion of Taiwanese nationalism. Set in 1986-1988, the story seems to allude to the great changes in Taiwan at that time, when the nation is gradually veering away from pro-unification policy, and when economic prosperity enables Taiwan to emerge as one of the four little dragons of East Asia.

\section{Notes of a Desolate Man: a dissembling yuppie gay man's ambivalence}

Like 'A Romance about Forbidden Desire', Chu Tien-wen's novel Notes of a Desolate $\mathrm{Man}^{30}$ (1994) does not deal with father-son relationships, but unlike 'A Romance about Forbidden Desire' the novel is divided between endorsing and disparaging gay lifestyle. In this light its sexual politics seems closer to that of Crystal Boys. Written in a highly aesthetic modernist style, however, Notes of a Desolate Man is at once gayer, more decadent, more intellectual and more Westernised than Crystal Boys. A large part of Notes of a Desolate Man in fact consists of the narrator reading notes of Western literary theories and films.

The novel presents the first-person narrator, Little Shao, as a Taiwan gay man at 40, who is familiar with but has great reservations about Western gay and queer discourses. A cowardly, dissembling, closeted gay man, he strongly endorses mainstream heterosexual family values, apologising for his gay identity and denigrating the gay men's promiscuous practice within certain circles. Nevertheless, he also expresses a yearning for transgression and rebellion from time to time. At the very outset of the novel, Little Shao the 'desolate man' states in a tone of regret reminiscent of Eliot's The Waste Land: 'This is a time of decadence, this is a time for prophesy'. ${ }^{31}$ On the one hand he upholds Levi-Strauss's theory of kinship structure, thereby vilifying homosexuals as 
freaks. On the other, he also foresees a sexual paradise in Foucault's The History of Sexuality:

in a sexual terrain where every obstacle is abolished, two women (or two men) explore sexuality with each other, to see how the horizon of sexual pleasure can be ever expanded. Totally dissociated from the procreative function, sex is sublimated into sex for sex's sake. It is thus a sensual, aesthetic, artistic, and erotic kingdom. ${ }^{32}$

Little Shao laments that a non-reproductive society is doomed to extinction, but the more he senses the sad fate of the erotic kingdom, the more he savours his aesthetic vision of decadence. Little Shao has reached the state of sexual depletion and craves a stable love relationship. He remains an aesthete and misses his decadent past life despite his denigration of it.

An apparent distinction between North American and Taiwan gay men's lives is suggested in the disagreement between Little Shao and his old friend Ah-yao. When Little Shao was still confused about his sexual identity, Ah-yao was already a happy gay man. Little Shao practised promiscuous, even anonymous, sex after being jilted by his lover and before meeting Yung-ji. In contrast, Ah-yao, who dies of AIDS, has been promiscuous and militant all his life. When the post-AIDS Queer Nation adopts defiant and seductive strategies, Ah-yao, who seems to live in New York, is among the activists who cry out 'Act up. Fight back. Fight AIDS. ${ }^{33}$ Little Shao, who only wants to have a secure life with Yung-ji, is horrified by Ah-yao's militancy. Shocked by Ah-yao's insatiable sexual desire, he feels vindicated by the fact that the lonely Ah-yao constantly makes international phone calls to him after having casual sex.

Despite Little Shao's disapproval of Ah-yao, it would be reductive to say that their difference stands for the difference between the global and the local. For one thing, Little Shao has also indulged in decadence in the past; his change in sexual attitude has to do with the fact that he happens to find a perfect lover in Yung-ji, whereas Ah-yao evidently has unrequited love for Little Shao, which the latter learns only too late. For another, Little Shao portrays a spectrum of different sexual practices in several yuppie gay men's circles, which sheds some light on the local gay community. And obviously not every yuppie Taiwan gay man he knows wants to keep a stable love relationship. Regardless of their sexual modality, these well-off gay men live comfortably and happily with their sexual identities, even though they do not come out and stand up for the gay movement. ${ }^{34}$ Interestingly, the choreographer Chieh stresses the institutionalisation of male homosexuality in ancient Greece, Hawaii and Japan, justifying his promiscuous practice through these international examples. Likewise, Little Shao eventually sees the necessity of using globalisation to help release what is repressed in the local. He finds a hero in Ah-yao, thinking that Ah-yao deserves a panel on the Names Project quilt, in North American gay communal mourning of those who die of AIDS. He even associates Ah-yao in recollection with Buddha. Despite Little Shao's denigration of practitioners of promiscuity as lechers, he cannot help respecting Ah-yao for bolstering positive images of gayness. Such images enable him to fantasise that Buddha is gay, to imagine that the crucified Jesus is branded with the kisses of his betrayer.

In presenting the yuppie gay circles in which Little Shao lives, the female 
author Chu Tien-wen taps into both Taiwan and Western fin de siècle aestheticism from a feminist perspective. The global and the local are thus seen as a harmonious hybrid. Through Little Shao, the novel celebrates a feminine aesthetic, in order not only to challenge traditional disparagement of femininity and woman, but also to assert the legitimacy of gay men. The novel accounts for some gay men's 'cruel' sexual practice of promiscuity by attributing it to the practitioner's aestheticising temper, even though it is also critical of such aestheticising. The effeminate Little Shao sees himself as having 'a feminine soul budding in a male body', ${ }^{35}$ with a feminine mentality. For him, although not every gay man is as effeminate, they all have an aesthetic penchant for matter, physique and appearance. Thus they all have an androgynous soul: 'We all have a femininity that is gazed at and a masculinity that gazes.' ${ }^{36}$ Adoring beauty rather than money or power, these male homosexual circles valorise male icons. Physical limitation, however, prevents anyone from being always the conqueror of love. 'The principles of the [homosexual] underworld' are 'doomed cycles of betraying and being betrayed' and 'never love again, lest you get hurt'. ${ }^{37}$ As sexuality is disentangled from the social network of marriage, family and reproduction, gay men can enjoy anonymous sex.

One may say that Little Shao's ruminations reveal that his endorsement of the mainstream heterosexual order is less sincere than a strategy for survival. On the issue of his relation with the nation, he is even more divided, if not self-contradictory. On the one hand, he appropriates communist terminology to connect the marginality of the (decadent) male homosexual underworld with Left politics by saying that this underworld is 'a hedonist commune', and that 'homosexuals don't have a fatherland' ${ }^{38}$ On the other, he draws from ancient Chinese texts to express his allegiance to and nostalgia for the government of the late President Chiang Kai-shek. Despite the fact that Chiang's authoritarian pro-unification government suppresses sexual and ethnic others as well as political dissidents, he considers it the 'perfect order', all because he is a mainlander's son. Obviously, his double attitudes toward the nation indicate his different subject positions: speaking as a gay man, he is against nationalism, whereas speaking as a mainlander's son, he is an ardent adherent of a Chinese nationalism that is all but lost. He is embittered by the mainlanders' loss of power to native-born Taiwanese after the lifting of martial law. Even so, he painfully comes to realise that it is impossible for the Kuomintang to take back China from the communists, and that the China he loves so much is an abstract cultural notion rather than a political entity of today. A globetrotter, he nevertheless never visits China.

As Chinese nationalism gives way to Taiwanese nationalism, and as Chinese culture is superseded by Taiwanese culture in Taiwan, what is local strikes him as vulgar. ${ }^{39}$ Feeling politically and culturally in exile, he aligns himself more and more with Western and Japanese cultural products. Even here he cannot but note that Japan and the West are undergoing a shift in cultural paradigms similar to that in Taiwan. The rise of pop culture, which is related to the rise of teenage culture and buttressed by the lifting of martial law, helps create trends that are often distasteful to him. Thus, while his problems and concerns have some cultural specificity, they are also related to globalisation. 
Through Little Shao's ambivalence as a Taiwan gay man, the novel, which is set in the early 1990s, presents a spectrum of Taiwan gay men's sexual practices, a panorama of contemporary Taiwan culture as hybrid, and a reflection on Taiwan history. The highly complex novel at once celebrates gay men's decadent aesthetic and endorses mainstream family values. Its dissembling politic reflects the cosy affluence of closeted yuppie gay men who are integrated into the social order and find support from their own gay circles.

\section{4 'Rituals': a satire on heterosexism and homophobia}

Chi Ta-wei's short story 'Rituals' $(1995)^{40}$ departs from the three earlier texts by using writing strategies that mark the story as a 'ku-err hsiao-shuo' (or 'queer fiction', a newly coined term with 'queer' having the same meaning as in 'queer criticism' and 'queer studies') by an activist in the queer movement. A satire with a pro-sex stance, the story is closest to $\mathrm{Li}$ Ang's 'A Romance about Forbidden Desire' in tone. But since 'Rituals' is a satire on self-identified male heterosexuals, it is more seductive, more provocative and more carnivalesque.

By recourse to metafiction, the story unravels the homoerotic desire of a self-identified male heterosexual named Han in different stages of his life, in spaces from the family to school to the army. As the intrusive narrator repeatedly takes the reader to examine Han's devious trains of thought, fantasies and memories, he is literally queering Han's sexual subjectivity, and, by extension, that of his reader as well. The narrator's persistent highlighting of Han's homoerotic desire throughout his life suggests that Han is a closeted gay man, and that the ironic and funny part is that Han never realises or allows himself to realise this.

Unlike the three earlier texts, 'Rituals' does not have a character who lives or had lived abroad. Even so, its writing strategies strike one as 'westernised'. In particular, the queer family romance that the story portrays not only subverts the traditional father-son relationship in Taiwan, but is a satire on the kind of familialism that Crystal Boys and Notes of a Desolate Man are reluctant to challenge. Since male homosexuality is taboo, Han can only displace his desire onto an adoration for his late father, whom he has never seen except in a photo: 'If he, too, has ever loved a man, that man must be the saint in snow white robe in the black-and-white picture. ${ }^{41}$ His desire is further bizarrely displaced onto an apparent heterosexual love for his daughter, simply because she inherits his father's noble masculinity: 'His own father, assuming the image of his own daughter, appears right before him-resurrected. ${ }^{42}$ In his subconscious, he imagines that the spirit of his father leaves his mother, inhabits his own blood, finds its way into his robust semen, which he ejaculates into his wife's body, and creates his daughter. This amounts to almost a fantasised incestuous relationship with his father, with his wife serving as the surrogate container of the fetus. ${ }^{43}$ Even more provocative is the episode where, when still a high school student, Han is aroused by looking at his virile father in the photo, and masturbates while imagining that he and the pictorial figure consummate this desire.

In a defiantly comic spirit, the narrator unsettles the complacency of homophobic heterosexist men by giving a convincing, realistic characterisation of 
a well-to-do, middle-aged, married, native-born Taiwanese man, complete with details of his childhood, adolescence and adulthood, before queering his sexual unconscious. Whereas Han recalls his male friendships in high school and military service, and repeatedly denies the eroticism involved, the narrator deconstructs his memories as a flawed text, full of contradiction and deliberate erasure. The narrator exposes to us how the 'facts' and 'memories' which Han convinces himself are true are distorted by the mechanism of compulsory heterosexuality into inauthentic, implausible texts. The narrator notes that 'facts' are so complex and many-sided that they cannot be grasped in full ("the matrix of "facts" is like a mass of ever-expanding, ever-disintegrating embryo'). ${ }^{44}$ Most importantly, he finds that the cause-effect relationships are often a retrospective invention in reconstructing the past:

'Cause-effect relationships' becomes the name of a video game. 'Because' and 'so' become tokens for game players. Isn't that funny? ... You can't even distinguish whether it's a token of 'because' or 'so' ... . Or perhaps you may find that the token turns out to be a fake one (but in fact a token is already fake money). ${ }^{45}$

The title suggests that mainstream heterosexual values mould and shape individuals through all kinds of rituals or rites of passage, and that the more one is socialised, the more one may repress one's true desire. But such moulding is never entirely successful. One of the most hilarious jokes in the novel is the way Han fantasises about heroic rituals. Han is portrayed as tending to find an outlet for his homoerotic desire in hero worship. He romanticises those who died heroically either on a Japanese suicide air attack mission during World War II or during the reign of terror subsequent to the 2-2-8 incident in 1947. Thus his desire is intertwined with his reconstruction of Taiwan's colonial past. The exoticism of his father in a Japanese white robe triggers Han's fantasies. Believing that his father was a Taiwanese glorious samurai co-opted by the Japanese Royal Army, he imagines that he was killed as the pilot of a suicide plane during World War II. He fantasises that his father's plane 'penetrated' the US warship, and is in fact aroused by this fantasy. (The narrator undermines his hero worship by pointing out that, instead of being a soldier, his father was actually a bum who whiled away his time in the brothels.) Likewise, Han idolises those romantic communists who were executed during the turmoil subsequent to the 2-2-8 incident. For him, they were the idealists who sacrificed their lives heroically.

Han's sentimental attachments for the victims in the 2-2-8 incident and for his reportedly Taiwanese Japanese father seem to mark him as a sort of Taiwanese nationalist. For the attachments are predicated on a tacit recognition of Taiwan's colonial ties with Japan and Taiwanese suffering in the 2-2-8 incident. Han's is a moderate form of Taiwanese nationalism, however, since he also sees himself as a citizen of the Republic of China. ${ }^{46}$ By queering Han, Chi Ta-wei, then, is also queering the stereotype of the heterosexist Taiwanese nationalist.

As a hilarious, provocative satire on homophobia and heterosexism, 'Rituals' insinuates that even self-identified heterosexuals may unwittingly lock their homoerotic desire in the closet of their unconscious. Its queering of family romance and a moderate brand of Taiwanese nationalism is a register of its defiant sexual politics. 


\section{Conclusion}

As the globalisation process dismantles the boundaries between nation-states and cultures, incommensurable differences are also produced in the process of cultural translation. Numerous hybrid sites of meaning indicate the intersection of the global and the local. The four fictions, which deal with male homosexuality, show different sexual politics, and concerns that reveal both exposure to Western gay and queer discourses and sensitivity to local conceptions of male homosexuality at the time of their writing. Pai Hsien-yung's Crystal Boys aims at a 'collective coming out', but its liberal humanism and reconciliation with paternal authority undercut its subversive potential. Both Li Ang's 'A Romance about Forbidden Desire' and Chi Ta-wei's 'Rituals' shake off the familialism that obsesses Crystal Boys, and are much gayer in tone, while Chu Tien-wen's Notes of a Desolate Man is ambivalent and ambiguous, as the dissembling narrator both endorses heterosexual family values and celebrates the decadent aesthetic. Partly because it focuses on homosexual prostitutes, Crystal Boys to some extent still conflates male homosexuality with curse, guilt, lust or tragedy. The other three texts all take for granted gay men's sexual identity and pleasure, even though the narrator of Notes of a Desolate Man sometimes denigrates male homosexuality. And 'A Romance about Forbidden Desire' rewrites Crystal Boys by satirising LA gay men linking the Taipei homosexual prostitute with curse and tragedy. 'Rituals' is even more defiant and seductive than 'A Romance about Forbidden Desire', since it satirically reveals that a smug heterosexist, homophobic married man is a closeted gay man.

The overlapping of sexual with racial or ethnic politics in these texts further throws light on the intersection between the global and the local. In Crystal Boys, Wang Kuei-lung's home-coming signifies the home-coming of the mainlander's son and a compromise with paternal authority, whereas Little Jade's search for his biological father is an assertion of his right as a homosexual, a connection with the international gay community, and a recognition of Taiwan's colonial past. 'A Romance about Forbidden Desire' subverts the superiority of First World gay men by stressing the subjectivity of the Taiwanese homosexual prostitute, and is a parable of Taiwan's reemergence onto the international scene with a national identity. Notes of a Desolate Man both underscores gay men's anti-establishment, anti-nationalism stance, and expresses a nostalgia for 'the good old days' under martial law when the mainlanders took control and when Chinese nationalism was the dogma. And 'Rituals' audaciously queers Taiwanese nationalism, while recognising both Taiwanese colonial ties with Japan and Taiwanese suffering in the turmoil subsequent to the 2-2-8 incident.

\section{Notes}

${ }^{1}$ See Mike Featherstone, Undoing Culture: Globalization, Postmodernism and Identity, London: Sage Publications, 1995, pp 6, 102.

${ }^{2}$ Featherstone, Undoing Culture, p 102.

${ }^{3}$ Homi Bhabha, The Location of Culture, London: Routledge, 1994, p 1.

${ }^{4}$ Featherstone, Undoing Culture, p 103.

${ }^{5}$ For a discussion of the change in notions of gender and sexuality in 1990s Taiwan in relation to 
globalisation and localisation, please see my article 'Gender Crossing and Decadence in Taiwanese Fictions at the "fin de siecle": The Instances of Li Ang, Chu Tien-wen, Chiu Miao-jin, and Cheng Ying-shu', Chung-wai Literary Monthly, November 1999, 28, 6, pp 109-131.

${ }^{6}$ The conflict is probably more complicated than is discussed here. See also note 9.

${ }^{7}$ See Hsiao-hung Chang, 'Queer Politics of Desire', Chung-wai Literary Monthly, June 1996, 25, 1, pp 6-25.

${ }^{8}$ Bhabha, The Location of Culture, p 163.

${ }^{9}$ There were debates about whether or not the masking strategy was successful. While Chang Hsiao-hung is positive that the strategy was enabling in stressing gay/lesbian/queer subjectivity, Lin Hsien-hsiu and Chao Yen-ning criticise the strategy as making it harder for the public to affirm gays, lesbians and queers, since masking seems to subject gays, lesbians and queers to the social order which does not want to see them except in heterosexual masks. See Fran Martin, 'Closets, Masks and Membranes: The Homosexual Subject's Yin/Xian Logic in Contemporary Taiwan Discourse', trans. Ta-wei Chi, Chung-wai Literary Monthly, May 1998, 26, 12, p 133.

${ }^{10}$ Ta-wei Chi, 'Queer Diaspora: A Queer Reading of Notes of a Desolate Man', Chung-wai Literary Monthly, August 1995, 24, 3, p 156.

11 Ta-wei Chi, 'Queer Diaspora', pp 153-160.

12 Ta-wei Chi, 'Queer Diaspora', pp 158-159.

13 Ang Lee's The Wedding Banquet received an international film award in 1994, as did Tsai Ming-liang's The River in 1996.

${ }^{14}$ Chu Tien-wen's Notes of a Desolate Man was honoured in 1994 and Chiu Miao-jin's Notes of a Crocodile in 1995.

15 Hsien-yung Pai, Crystal Boys, Taipei: Er-ya, 1983. The novel was first published in serial form in the literary journal Modern Literature from 1977 to 1978.

${ }^{16}$ Yeh Te-hsuan sums up these earlier criticisms and points out the homophobic and heterosexist prejudices in each one of them. See Te-hsuan Yeh, 'The Haunting Specter of Familialism: A Discursive Analysis of Some Commentaries on Crystal Boys', Chung-wai Literary Monthly, December 1995, 24, 7, pp 66-88.

${ }^{17}$ In her book Modernism and the Nativist Resistance, Chang Sung-sheng uses Bakhtin's notion of heteroglossia to read this novel, and sees it in relation to the Chinese decadent tradition and the Western gay movement. Following Chang's example, Yeh Te-hsuan had first challenged earlier criticisms of Pai in 1995, pointing to their bias (see note 16). Then, in 1998, Yeh published another article discussing the carnivalesque and subversive elements in the novel. Chang is admirable in initiating a new direction of Pai criticism. But sometimes her interpretation makes the novel sound more progressive than it actually is. For instance, Chang claims that 'The thematic thrust of the novel Crystal Boys ... may be seen as partaking in the celebration of the Dionysian impulse-libidinal ecstasy and anxiety, the unresolved tension of sexual longing, and an obstinate refusal to be re-absorbed into a bland order.' See Sung-sheng Chang, Modernism and the Nativist Resistance: Contemporary Chinese Fiction from Taiwan, Durham: Duke University Press, 1993, pp 95-96. See also Te-hsuan Yeh, 'The Haunting Specter of Familialism', and Te-hsuan Yeh, 'Go Camping: Gender Crossing Performances in "The Fabulous Yin Hsueh-yen” and Crystal Boys', Chung-wai Literary Monthly, May 1998, 26, 12, pp 67-89.

${ }^{18}$ See, for instance, Pai Hsien-yung's short stories 'Mamason Jin's Last Night' (1968) and 'Lone Flower' (1970) (both collected in Pai Hsien-yung's Taipei People, Taipei: Er-ya, 1983); Huang Chuen-ming's short story 'Sayonara! Goodbye' (1974) (collected in Huang Chuen-ming's Sayonara! Goodbye, Taipei: Yuanching, 1974); and Wang Jen-ho's novel Rose, Rose, I Love You, Taipei: Yuan-ching, 1984.

19 All references to the Taiwanese fictions are to their Taiwanese version. Hsien-yung Pai, Crystal Boys, Taipei: Yun-chen, 1990 (1983), p 3.

${ }^{20}$ It should be noted that, when the wildness of the young birds is celebrated, it is often associated with Taiwan, since these young birds all have native-born Taiwanese parents or parent. Certainly this association borders on essentialising Taiwanese and Taiwan. Unlike Pai Hsien-yung's earlier work, Taipei People, in which the characters see themselves as mainlanders who live only temporarily in Taiwan, Crystal Boys is as much concerned about Taiwanese and Taiwan as about mainlanders and China.

${ }^{21}$ Tzu Ou-yang, 'The Fictional World of Pai Hsien-yung: A Thematic Study of Taipei People', Taipei People, pp 16-22.

22 Instead of the flesh and spirit dichotomy, Chang proposes the Chinese notions of $c h$ 'ing and $y u$. According to Chang's explanation, ch'ing and $y u$ are a 'two-in-one concept' with ch'ing 'connoting both amorous passion and plain sentimentality' and $y u$ representing 'animalistic desire'; see Sung-sheng Chang, Modernism and the Nativist Resistance, p 94. Chang argues that in Crystal Boys, 'The author apparently sympathises not only with those possessing ch'ing, but also with those helplessly tormented by $y u$ '; see Modernism and the Nativist Resistance, p 109. But such sympathy hardly alters traditional views of male homosexuality as a curse: in Chang's own words, 'This sympathy is justified by Pai's interpretation of the source of ch'ing and $y u$ as hereditary .... The new interpretation would suggest that the sons themselves are burdened by a curse'; see Modernism and the Nativist Resistance, p 109.

${ }^{23}$ See Sung-sheng Chang, Modernism and the Nativist Resistance, p 111. 
${ }^{24}$ Ang Li, 'A Romance about Forbidden Desire', in The Dark Night of Forbidden Desire: A Collection of Erotic Short Stories by Li Ang, Taipei: Crown, 1999, pp 7-52.

${ }^{25}$ Since Wang Ping never identifies himself as a Taiwanese American, I find it difficult to name him so. He actually views himself as less a Chinese American than an American. It is obvious that he sees Americans as superior to Chinese, and Chinese as superior to Taiwanese.

${ }^{26}$ At first Wang is under the impression that Lin accosts Brown because he likes to be associated with foreigners. Probably to show off, Wang tells Lin that he himself is based in the United States. But he soon finds that Lin just enjoys having sex with foreigners, and that Lin never wants to go abroad.

27 The narration of the story alternates between an anonymous female, who is a heterosexual friend of theirs, and an omniscient author.

28 The anonymous female narrator compares the values in mainstream society and the male homosexual community, and explores the differences in class and culture (including ethnicity and nationality) within the male homosexual world. See also note 25. Moreover, as a native-born Taiwanese, she is sensitive about the coming into being in the 1980 s of a new proud native Taiwanese identity vis-à-vis mainlanders both in Taiwan and in China. Thus while Wang Ping dubs her as displaying a 'new rich Taiwanese mentality', she takes it with a sense of humour. Speaking at a time when many Taiwanese are disillusioned by what they see in mainland China (after they are allowed to visit it), the narrator pits her so-called 'new rich Taiwanese mentality' against Chinese chauvinism to satirise the privileging of Chinese over Taiwanese culture in Taiwan from 1947 to 1987 . She sees the privileging as a failure to recognise the subjectivity of Taiwan and Taiwanese.

${ }^{29}$ In 1971 Taiwan lost the United Nations China seat. And in 1979 Taiwan received another blow as the US withdrew recognition of the Republic of China in Taiwan in favour of the People's Republic of China on the mainland. Taiwan became an international pariah state as many other countries also withdrew diplomatic recognition. Taiwan's economic strength and important geopolitical location, however, have helped the island out of this isolation.

30 Tien-wen Chu, Notes of a Desolate Man, Taipei: Shih-pao, 1994.

31 Tien-wen Chu, Notes of a Desolate Man, p 9.

${ }^{32}$ Tien-wen Chu, Notes of a Desolate Man, pp 64-65.

33 Tien-wen Chu, Notes of a Desolate Man, p 11.

${ }^{34}$ While there is no direct reference to the local gay movement, Little Shao's jibes about scholars who do queer studies ('These scholars only play with words, with the signifier never having anything to do with the signified, since they never know the existence of a [queer] subject. The scholars are only doing intellectual exercises, using mental technique to replace reality, in order that they can survive in the academy') seem to be targeted at scholars both at home and abroad. See Tien-wen Chu, Notes of a Desolate Man, p 59.

${ }^{35}$ Tien-wen Chu, Notes of a Desolate Man, p 99.

${ }^{36}$ Tien-wen Chu, Notes of a Desolate Man, p 97.

37 Tien-wen Chu, Notes of a Desolate Man, pp 83, 144.

38 Tien-wen Chu, Notes of a Desolate Man, p 145.

${ }^{39}$ His resentment is tied to his reservations about Western multiculturalism.

40 Ta-wei Chi, 'Rituals', in Queer Senses, Taipei: Ping Shih, 1995, pp 51-91.

${ }^{41}$ Ta-wei Chi, 'Rituals', p 54.

${ }^{42}$ Ta-wei Chi, 'Rituals', p 55.

${ }^{43}$ Ta-wei Chi, 'Rituals', p 55.

44 Ta-wei Chi, 'Rituals', p 78.

${ }^{45}$ Ta-wei Chi, 'Rituals', pp 83-84.

46 Ta-wei Chi, 'Rituals', p 82. 
Copyright $\odot 2003$ EBSCO Publishing 